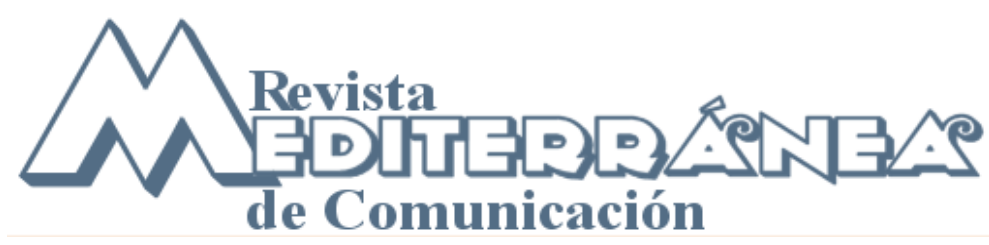

\title{
LOS PROTAGONISTAS DE LAS PELÍCULAS COLOMBIANAS 1990-2003
}

\author{
Jerónimo León Rivera Betancur ${ }^{1}$ \\ Universidad de La Sabana (Bogotá- Colombia) \\ jeronimo.rivera@unisabana.edu.co
}

\section{Resumen}

El cine colombiano es el objeto de estudio de este artículo, que parte de los resultados de la investigación "Personajes, acciones y escenarios en el cine colombiano de 1970-2005", realizada en la Universidad de Medellín (Colombia) entre 2005 y 2007. Se trata de un artículo de revisión en el que se hace un análisis narrativo de la representación de personajes protagónicos en las películas colombianas de la década de 1990 hasta 2003 (año de la puesta en marcha de la ley del cine en Colombia). Se abordan algunas películas de la muestra y en cada una se hace un análisis de los personajes más representativos.

\section{Palabras clave}

Cine, artes visuales, Colombia.

\section{Abstract}

The Colombian cinema is the object of study of this article, which departs from the results of the research "Prominent figures, actions and scenes in the Colombian cinema of 1970-2005 ", realized in the University of Medellin (Colombia) from 2005 to 2007. It is an article of review a narrative analysis of the representation of leading prominent figures in the Colombian movies of the decade of 1990 until 2003 (year of the putting in march of the law of the cinema in Colombia). Some movies of the sample are approached and in each one there is done an analysis of the most representative prominent figures.

\section{Key Words}

Cinema, visual arts, Colombia.

\section{Introducción}

La historia del cine en Colombia ha sido accidentada y poco sistemática, sujeta a los avatares de las políticas culturales y, la mayor parte de las veces, poco apoyada por un público nacional que no logra conectarse con muchas de las historias que esta cinematografía presenta.

Muy pocos años después de la fecha oficial de la invención del cine, 28 de diciembre de 1895, el cine llegó a Colombia de la mano de camarógrafos europeos que registraron los paisajes colombianos como parte de un mundo exótico y desconocido para los habitantes del viejo mundo. 
Hay registros históricos, aunque no evidencias, de que en 1897 se proyectaron por primera vez algunas cintas en improvisadas salas de cine nacionales y de que en 1899 se filmaron y exhibieron las primeras imágenes del país. Algunos extranjeros residentes en Colombia y que acostumbraban viajar a Europa trajeron las primeras cámaras y con ellas pudieron hacer los primeros registros. Entre este grupo de extranjeros, la mayoría de ellos fotógrafos, se destacaron los hermanos Di Doménico, que en 1914 fundaron la SICLA (Sociedad Industrial Cinematográfica Latinoamericana) que funcionó hasta 1928 haciendo un importante aporte al naciente cine nacional.

En 1922 se estrena María, la primera película de largometraje realizada en Colombia y dirigida por Máximo Calvo. Esta película, basada en la obra homónima del escritor colombiano Jorge Isaacs es un buen reflejo de lo que sería el cine colombiano de los primeros años: un cuadro costumbrista y romántico de un país fundamentalmente rural.

En el período de 1922-1942 sólo se realizaron veinte películas en Colombia, algunas de las cuales ni siquiera fueron exhibidas, y en ellas fue recurrente la mirada idealizada, romántica y algo ingenua del país con un notorio subdesarrollo técnico si tenemos en cuenta que a nivel mundial el lenguaje cinematográfico muestra un alto grado de madurez y riqueza visual hacia 1925 en la época del cine silente. Lamentablemente, ninguna de estas producciones ha sobrevivido íntegramente al paso del tiempo y sólo se conservan fragmentos de largometrajes o versiones restauradas $^{2}$

La historia de las compañías productoras de este período es corta y poco significativa. En 1938 se fundó Colombia Films que fracasó poco tiempo después, En 1943 nació Patria Films que alcanzó a filmar tres películas, un año después nació Cofilma que realizó dos largometrajes. Sólo en 1947, Camilo Correa fundó la productora Procinal, la única que como exhibidora permanece aun en Colombia.

En 1939, de acuerdo a la tendencia mundial, Colombia entró en la onda de los informativos cinematográficos con el noticiero Ducrane que emitió cientos de entregas entre 1939 y 1946. Como éste, surgieron otros importantes espacios como los noticieros Nacional, Colombia y Del Caribe, que se mantuvieron hasta 1971. Los noticieros se producían y exhibían en Colombia y fueron fundamentales para generar el oficio, la técnica y la experiencia que se requería para la puesta en marcha de la televisora nacional el 13 de junio de 1954, bajo la dictadura del Teniente General Gustavo Rojas Pinilla.

Lastimosamente muchas de las películas realizadas en Colombia antes de $1960^{3}$ se dañaron o perdieron en archivos familiares, ante la falta de políticas estatales de preservación y la fragilidad de los materiales cinematográficos.

En las décadas del 60 y el 70 fue evidente la influencia de la escuela documentalista latinoamericana y de las tendencias marxistas que se expresaron en movimientos estéticos e ideológicos inspirados en el neorrealismo italiano y la nueva ola francesa y que se plasmaron en movimientos latinoamericanos importantes como el cinema novo brasileño y el cine militante argentino. Una nueva camada de jóvenes directores de cine educados en escuelas de cine extranjeras y con una gran influencia marxista, llevó a la gran pantalla historias de denuncia, inspiradas en el conflicto interno colombiano y en las desigualdades sociales.

El período fue rico en películas documentales de gran contenido social y algunos largometrajes de ficción que abordaron este tema, desde un punto de vista militante haciendo énfasis en la denuncia y la marginalidad. El cine del período toma posición y pone el dedo en la llaga de los problemas del país. De igual manera, esta tendencia sirvió para que otros realizadores se fueran al extremo y realizaran una buena cantidad de títulos de lo que se ha denominado la 
"pornomiseria", películas que se vendían muy bien en Europa y Estados Unidos por presentar historias cotidianas escandalosas con muy poca investigación y un gran impacto sensacionalista.

Este fenómeno de la pornomiseria fue bien caracterizado y parodiado por los directores Luis Ospina y Carlos Mayolo en su cortometraje de 1977 Agarrando Pueblo. Sobre este cortometraje, fundamental para el cine colombiano, Luis Ospina (1999) afirmó: Esto fue como un escupitajo en la sopa del cine tercermundista, y por ello fuimos criticados y marginados de los festivales europeos y latinoamericanos, acostumbrados a consumir la miseria en lata para tranquilidad de sus malas conciencias. Pero a la larga tuvimos razón porque después de la polémica la situación se volvió apremiante y comenzamos a cosechar premios en los mismos festivales que nos habían excluido.

Las películas con contenido comercial, institucionales, turísticas y de temáticas ligeras fueron, no obstante, la cuota predominante del cine nacional de estos años.

En 1978 surge la Compañía de Fomento Cinematográfico (FOCINE), el primer intento estatal serio de apoyar la incipiente industria nacional. Desde su surgimiento hasta su cierre en 1993 fue objeto de toda clase de polémicas por la promoción de la realización de películas en gran cantidad y la baja calidad de la mayoría de estas producciones.

Este período es conocido también como el sobreprecio, fijado desde 1974, pues la política estatal se fundamentaba, entre otras cosas, en el cobro de un sobreprecio a cada boleta para el apoyo del cine nacional y la exhibición de un cortometraje nacional al inicio de cada película. Este fondo fue fundamental para la producción de una buena cantidad de películas en Colombia, pero también fue objeto de numerosas estafas, debido a los graves vacíos jurídicos que tenía y a la inexperiencia en término de derechos de autor, producción cinematográfica y políticas culturales en el país. Al respecto, Laurens (1988) comenta que "el sobreprecio se convirtió en una carnada para enriquecer a no pocos oportunistas, quienes siguen mirando el cine como próspero negocio y jamás se preocupan por su expresión artística".

El cierre de FOCINE en 1993 sumió al país en una profunda crisis de realizaciones cinematográficas que llevó a que bajara ostensiblemente la producción de películas por año, al punto de que en los dos años posteriores al cierre de FOCINE sólo se estrenaran dos largometrajes nacionales.

Entre 1990 y 2003, año en el que se promulgó la Ley del Cine, se exhibieron 38 películas colombianas para un promedio de 2,7 películas por año, un promedio muy bajo comparado con países como Argentina, Brasil o México que, por ejemplo, realizó 365 películas durante estos 14 años ${ }^{4}$. La puesta en marcha en 2004 del Fondo para el Desarrollo Cinematográfico, que administra los dineros recaudados por la ley del cine, ha posibilitado que entre 2004 y 2008 se exhiban 43 largometrajes para un promedio de 8,6 películas por año. Este aumento en la producción de películas de largometraje ha generado voces optimistas en el país que han llegado a hablar del auge de la producción o del resurgimiento del cine colombiano. Este panorama, sin embargo, no es tan optimista cuando se examinan las cifras de ingreso por taquilla para cada película y la cantidad de semanas que éstas se exhiben en la cartelera.

Todo esto ha generado que la imagen del "cine nacional" sea difusa. Parecería que no hay elementos comunes en esa producción, que al ser proyectos aislados narraran un país diferente y que las formas de narrar no tuvieran elementos comunes. En nuestro país no hay "escuelas" y de pocos directores se puede afirmar que tengan un estilo definido. Las temáticas parecen repetirse, por ciclos y sin embargo parecería que no se retoma nada de las producciones anteriores. Es decir, al parecer no hay tradición en la producción y cada vez se empieza de nuevo, impidiendo así una clara conformación de un cine de calidad que recoja los aprendizajes de las producciones anteriores. 
Sin embargo, al mirar el listado y conocer el contenido de la mayoría de los filmes, puede inferirse que en esos 197 largometrajes hay elementos comunes en temáticas y en elementos narrativos que vale la pena analizar, pues allí podrían encontrarse algunas claves de análisis y lectura de nuestro cine como representación de nuestra realidad. Una realidad tal vez tan difusa como nuestro cine mismo.

Esta discusión, sin embargo, no alcanza a ser resuelta en este trabajo, que pretende abordar el período de 1990-2003 para indagar por el cine colombiano inmediatamente anterior a la promulgación de la ley del cine (ley 814 de 2003), tratando de indagar en la construcción narrativa de personajes protagónicos de las películas colombianas para determinar su caracterización y si su presencia genera la construcción de estereotipos o arquetipos de lo que significa ser colombiano.

\section{Metodología}

El trabajo de investigación partió de categorías previamente establecidas para un análisis narrativo basado en las nociones de personajes, acciones y escenarios para desglosar, por medio de una categorización propia del proyecto, cada uno de los elementos en subcategorías.

Para este trabajo, el grupo de investigación realizó por separado el análisis de las películas de la muestra partiendo en primera instancia del pietaje del material y la partición por escenas para terminar haciendo un análisis narrativo de cada categoría. Para la categoría de personajes, se tomaron aspectos relacionados básicamente con el rol del personaje en la historia y su caracterización definida en cada una de las dimensiones usadas por autores como Chris Vogler (Fisiológica, psicológica y social) y Linda Seger (privada, personal, social y profesional).

En el período analizado (1990-2003) se realizaron 39 largometrajes en Colombia, una cifra muy pequeña teniendo en cuenta que en los últimos 5 años (después de la puesta en marcha de la ley del cine) ya se han realizado 43. De estos 39 largometrajes fueron analizados 24, lo que constituye el $62 \%$ de las películas realizadas en el país en ese período.

El período analizado es muy importante, teniendo en cuenta que se trata de una pequeña crisis en la producción ya que son los últimos años de FOCINE y uno de los períodos históricos en el que el cine ha estado totalmente desprotegido por el Estado (1993-2003). El abordaje se hará por cada año, haciendo referencias a algunas películas y a las características recurrentes o excepcionales de los protagonistas de las mismas.

Las películas realizadas en este período son las siguientes:

Tabla 1

Películas del período

\begin{tabular}{|l|l|}
\hline 1990 & $\begin{array}{l}\text { Amar y Vivir de Carlos Duplat Sanjuán. } \\
\text { Confesión a Laura de Jaime Osorio Gómez. }\end{array}$ \\
\hline 1991 & -No se realizó ninguna película- \\
\hline 1992 & Un Hombre y una Mujer con Suerte de Gustavo Nieto Roa \\
\hline 1993 & $\begin{array}{l}\text { La Estrategia del Caracol de Sergio Cabrera. } \\
\text { La Gente de la Universal de Felipe Aljure. }\end{array}$ \\
\hline 1994 & Bésame Mucho de Phillipe Toledano. \\
\hline 1995 & Águilas no Cazan Moscas de Sergio Cabrera. \\
\hline 1996 & $\begin{array}{l}\text { Edipo Alcalde de Jorge Alí Triana. } \\
\text { lona Llega con la Lluvia de Sergio Cabrera. } \\
\text { La Nave de los Sueños de Ciro Durán. } \\
\text { Desasosiego de Guillermo Álvarez. } \\
\text { La Mujer del Piso Alto de Ricardo Coral. }\end{array}$ \\
\hline 1997 & La Deuda de Manuel José Álvarez y Nicolás Buenaventura. \\
\hline 1998 & Posición Viciada de Ricardo Coral. \\
\hline
\end{tabular}




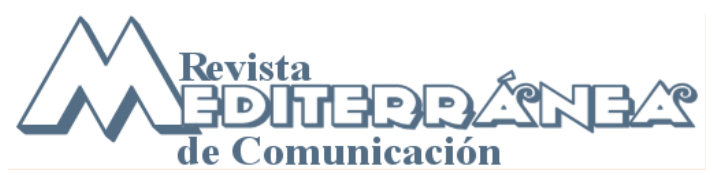

ISSN 1989-872X - Año 1 (2010), pp.36-50

\begin{tabular}{|l|l|}
\hline & $\begin{array}{l}\text { La Vendedora de Rosas de Víctor Manuel Gaviria. } \\
\text { Golpe de Estadio de Sergio Cabrera. }\end{array}$ \\
\hline 1999 & $\begin{array}{l}\text { El Último Carnaval de Ernesto MacClausand. } \\
\text { Rizo de Julio Sosa-Pietri. } \\
\text { El Séptimo Cielo de Juan Fischer. }\end{array}$ \\
\hline 2000 & $\begin{array}{l}\text { Es Mejor Ser Rico Que Pobre de Ricardo Coral. } \\
\text { Soplo de Vida de Luis Ospina. } \\
\text { La Virgen de los Sicarios de Barbet Schroeder. } \\
\text { Diástole y Sístole de Harold Trompetero. } \\
\text { La Toma de la Embajada de Ciro Durán. }\end{array}$ \\
\hline 2001 & $\begin{array}{l}\text { Siniestro de Ernesto MacClausand. } \\
\text { Terminal de Jorge Echeverri. } \\
\text { El Intruso de Guillermo Álvarez. } \\
\text { Kalibre 35 de Raúl García. } \\
\text { La Pena Máxima de Jorge Echeverri. } \\
\text { Bogotá 2016 D.C. de Ricardo Guerra - Jaime Sánchez - Alessandro Basile - Pablo Mora } \\
\text { Los Niños Invisibles de Lisandro Duque Naranjo }\end{array}$ \\
\hline $\begin{array}{l}\text { After Party de Julio César Luna } \\
\text { Bolívar Soy Yo de Jorge Alí Triana } \\
\text { Como el Gato y el Ratón de Rodrigo Triana } \\
\text { Te Busco de Ricardo Coral }\end{array}$ \\
\hline $\begin{array}{l}\text { Hábitos Sucios de Carlos Palau } \\
\text { La Primera Noche de Luis Alberto Restrepo } \\
\text { El Carro de Luis Orjuela } \\
\text { Bolívar, el Héroe de Guillermo Rincón }\end{array}$ \\
\hline
\end{tabular}

\section{Resultados}

García Jiménez, (1993) plantea que los elementos que constituyen la narrativa de los relatos son los personajes, las acciones y los escenarios; esta idea ha sido planteada por diferentes teóricos desde perspectivas tan distintas como la lingüística o la semiótica teatral ${ }^{5}$. Como en una ecuación matemática, restringir la importancia de uno de los elementos eleva automáticamente la importancia de los demás.

Al referirse a la relación entre los personajes y las acciones que los mismos ejecutan, García Jiménez (1993:276) plantea que La narración, en cuya teoría se asienta con firmeza el concepto de personaje, no puede ser mimesis de la acción sin serlo al mismo tiempo de los seres actuantes, en la medida en que éstos son sujetos que sienten y piensan. La enunciación se convierte en el discurso del narrador y el enunciado en el discurso del personaje.

Los personajes en el cine colombiano, son construidos en buena medida gracias al conflicto y allí encontramos una buena relación entre la ficción y la realidad. El cine latinoamericano ha sido un cine que ha estado permeado por los problemas de la subsistencia, la miseria y las desigualdades sociales y cuyo tratamiento, según la época, ha oscilado entre la autocrítica, la denuncia y la sátira. El cine colombiano no ha sido la excepción y podemos ver en nuestras películas a algunos personajes que conviven en medio de un conflicto que los afecta, los marca y que a muchos incluso los define.

En 2007, el grupo de investigación IMAGO de la Universidad de Medellín (Colombia) finalizó el proyecto de investigación "Personajes, acciones y escenarios en el cine colombiano de 19902005" y entre sus conclusiones más importantes está la de que el cine colombiano se ha construido fundamentalmente a partir de anécdotas, teniendo a la acción como elemento fundamental y dejando a los personajes como simples actantes, en el sentido de que son sujetos que realizan acciones y cuya complejidad es más bien limitada.

Al respecto, Álvarez (1989) sugiere que las grandes líneas argumentales son el terreno donde el cine colombiano sabe moverse bien. Los problemas surgen cuando hay que desarrollar las ideas, 
comenzar a explicar las situaciones y mantenerlas durante hora y media que es el tiempo de un largometraje según dicen las reglas del mercado.

En la investigación se encontró que muchos de los sujetos de los relatos no llegan a encarnar la posición de personajes de acuerdo con la definición de Linda Seger (2000:176), en la medida en que los personajes tienen una profundidad que los resalta de su entorno, una complejidad que los aleja de los personajes estereotipados, según afirma: Los personajes no estereotipados ayudan a que la historia avance mediante las actitudes, el comportamiento y los deseos ocultos e influyen, por lo tanto, en el desenlace.

A esta situación se suma una excesiva teatralización y una exageración visible en diálogos y actuación. No solo los personajes del cine colombiano tienden a tener deseos y conflictos relacionados solo con los impulsos más básicos, sino que los suelen enfrentar a gritos. Es decir, no solo son elementales e impulsivas sus acciones, sino que a ellas se añade una carga enorme de expresividad y emotividad (Uribe, 2009).

En un artículo publicado a partir de los resultados de la investigación "Personajes, acciones y escenarios en el cine colombiano 1990-2005" del grupo de investigación IMAGO, Vélez (2007) afirma que el nuestro es un cine que cuenta sus historias a partir de las anécdotas que guionistas, directores y productores viven, investigan o encuentran para convertirlas en imágenes y sonidos con sentido estético y comercial. Esta idea es reafirmada por testimonios como el de Marlon Moreno ${ }^{6}$, uno de los más importantes actores del cine y la televisión en Colombia cuando afirma que el cine Colombiano está en una búsqueda de identidad y por eso se han contado muchas anécdotas... muchas películas que cuentan ciertos momentos pero que todavía no involucran a los seres humanos

Las historias se desarrollan a partir de una trama y son los protagonistas, según Fernández (2005:29) quienes llevan el peso de la acción y conducen la trama principal, entre ellos existe un conflicto que es la esencia del drama. La elección y caracterización de un protagonista es fundamental, pues este personaje es el hilo conductor de la narración y el que genera sentimientos de admiración, identificación o animadversión en el espectador de la historia.

Existen dos tendencias opuestas a la hora de definir a los personajes. Para la rama de los aristotélicos el personaje es acción. Al respecto podríamos recordar la noción de Aristóteles (1982:8) que plantea que En un drama, entonces, los personajes no actúan para representar los caracteres; incluyen los caracteres en favor de la acción, es decir, el personaje lo es en tanto actúa y está supeditado al alcance de sus acciones. La otra postura considera que el personaje actúa de una manera determinada por ser como es, de acuerdo a su psicología y biografía personal $^{7}$. Esto ha dado lugar a dos estilos de cine muy diferentes: los films americanos, también conocidos como películas de plot (argumento) y el cine europeo o de "characters" (personajes).

Esta diferencia de posturas se marca en los distintos autores con respecto a la importancia que le dan a lo que se ha llamado la "psicología de los personajes" que para algunos, como Carriere y Bonitzer pasa a un segundo plano después de las acciones. Al respecto, estos autores recomiendan: "Repetir tres veces en voz alta cada mañana aquella cita de Chejov (en su carnet de notas): Lo mejor es evitar toda descripción de un estado del alma. Hay que intenta hacerlo comprensible por las acciones de los héroes" (Carriere y Bonitzer. 1991- p. 48).

El concepto de héroe es fundamental en la teoría narrativa desde los primeros estudios de autores como Vladimir Propp (2000) y Georges Polti (1916) y es muy relevante para filmografías como la norteamericana que ha tenido una influencia muy relevante en el cine colombiano. Jorge Navas, uno de los más importantes directores de cine en Colombia afirma que generalizando, de manera un poco blasfema, diría que los americanos, que son nuestra escuela directa, parten de la acción como eje principal; la creación de personajes y sus psicologías es importante, pero no tanto como 
para los europeos, que son mas internos, mas psicológicos, más obsesionados con el pasado y la forma en cómo se manifiesta sutilmente en el presente ${ }^{8}$.

Es importante, igualmente, tener algún criterio para elegir quien es el protagonista de la película y al respecto García Jiménez (1993:243) es claro al afirmar que el personaje sirve de soporte a cierto número de calificaciones que no poseen o poseen en menor grado los otros personajes: representado/aludido o 'citado', con 'marcas'/ sin 'marcas', con genealogía/ sin genealogía, con nombre propio/anónimo o sin nombre, descrito/no descrito, con leitmotiv/sin leitmotiv.

Es, por lo tanto, muy importante escudriñar en la concepción de personajes que se ha manejado en el cine colombiano para mirar, entre otras cosas, que modelos de héroe o antihéroe se manejan y de qué manera esto permite o impide la identificación del público colombiano con los protagonistas de las películas nacionales.

\section{Los personajes protagónicos}

Para efectos de este ensayo se hará un análisis de 24 películas, lo que constituye una muestra del $79 \%$. El criterio de selección para cada una de las películas tiene que ver con su representatividad dentro del conjunto de películas de la historia del cine colombiano, de tal manera que cada una de las seleccionadas reúne características comunes con otros grupos de películas (trayectoria del director, rural-urbana, comercial-autor, entre otros).

Tabla 2

Caracterización demográfica de los protagonistas

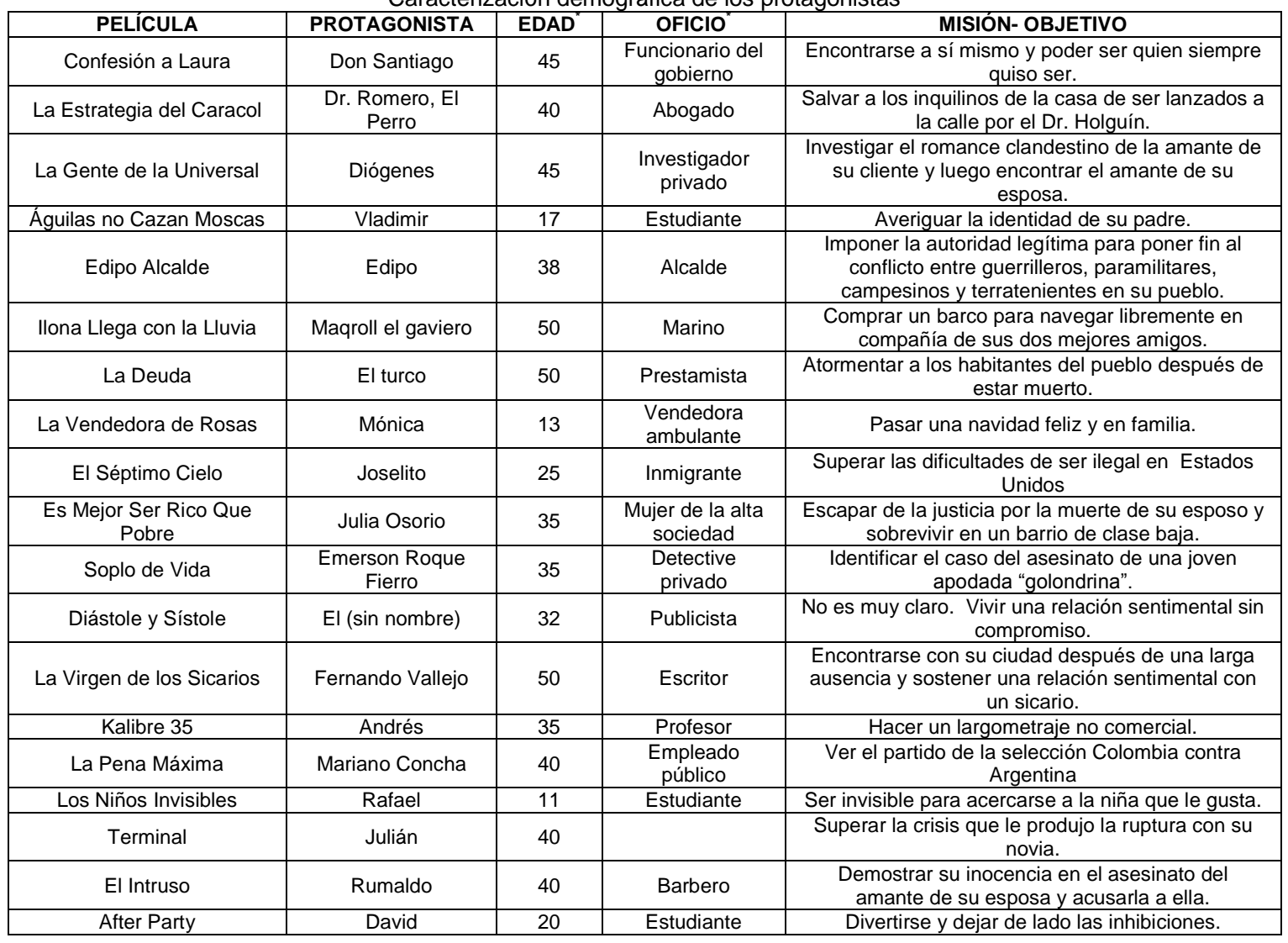

\section{"Aproximada}

* Puede ser oficio, profesión o rol profesional en la película (ejemplo: madre, inmigrante, ladrón, etc.). 


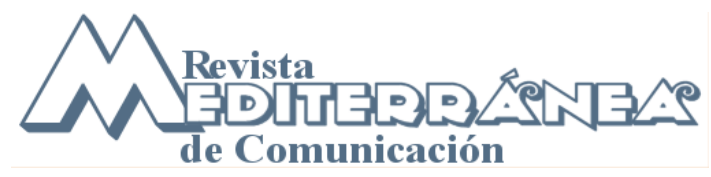

ISSN 1989-872X - Año 1 (2010), pp.36-50

\begin{tabular}{|c|c|c|c|c|}
\hline Bolívar Soy Yo & Santiago Miranda & 30 & Actor & $\begin{array}{c}\text { Convertirse en Bolívar para cumplir con el sueño } \\
\text { de unificación de las cinco naciones. }\end{array}$ \\
\hline Como el Gato y el Ratón & Cayetano Brochero & 45 & farmacéutico & $\begin{array}{c}\text { Demostrarle a su vecino y amigo que él es más } \\
\text { poderoso. }\end{array}$ \\
\hline Hábitos Sucios & Leticia & 35 & Religiosa & $\begin{array}{c}\text { Demostrar su inocencia en el asesinato de otra } \\
\text { religiosa por el que ha sido acusada. }\end{array}$ \\
\hline La Primera Noche & Toño & 30 & $\begin{array}{c}\text { Desplazado por } \\
\text { la violencia }\end{array}$ & $\begin{array}{c}\text { Sobrevivir junto a su cuñada y su sobrino bebé en } \\
\text { su primera noche como desplazado en Bogotá }\end{array}$ \\
\hline El Carro & Paola & 13 & Estudiante & $\begin{array}{c}\text { Celebrar su fiesta de 15 años y contar la historia } \\
\text { de la llegada del carro a la familia. }\end{array}$ \\
\hline
\end{tabular}

De esta muestra, se analizan en profundidad algunos de los personajes protagónicos (11) en un proceso de decodificación que implicó una partición del material en escenas, teniendo en cuenta diálogos, total de apariciones del personaje y caracterización física y psicológica.

Tabla 3

Caracterización de personajes protagónicos

\begin{tabular}{|c|c|c|c|}
\hline PELÍCULA & PROTAGONISTA & CUALIDADES & DEFECTOS \\
\hline Confesión a Laura & Don Santiago & Educado y respetuoso & $\begin{array}{l}\text { Inseguro, nervioso, reservado, } \\
\text { insatisfecho y poco sociable. }\end{array}$ \\
\hline $\begin{array}{l}\text { La Estrategia del } \\
\text { Caracol }\end{array}$ & $\begin{array}{l}\text { Dr. Romero, "El } \\
\text { perro". }\end{array}$ & $\begin{array}{l}\text { Líder, leal, ingenioso, } \\
\text { arriesgado, emprendedor y } \\
\text { luchador. }\end{array}$ & Tímido. \\
\hline $\begin{array}{l}\text { La Gente de la } \\
\text { Universal }\end{array}$ & Diógenes & Astuto, recursivo y sagaz & $\begin{array}{c}\text { Hipócrita, celoso, abusivo, } \\
\text { imperativo y egoísta. }\end{array}$ \\
\hline La Deuda & El turco & Inteligente & $\begin{array}{l}\text { Rencoroso, vengativo, abusivo, } \\
\text { cruel y despiadado. }\end{array}$ \\
\hline $\begin{array}{l}\text { La Vendedora de } \\
\text { Rosas } \\
\end{array}$ & Mónica & $\begin{array}{c}\text { Buena amiga, emprendedora, } \\
\text { ama a su familia. }\end{array}$ & Vengativa, violenta y rencorosa. \\
\hline Soplo de Vida & $\begin{array}{c}\text { Emerson Roque } \\
\text { Fierro }\end{array}$ & $\begin{array}{c}\text { Cauteloso, curioso, valiente y } \\
\text { arriesgado. }\end{array}$ & Inseguro y poco sociable. \\
\hline Diástole y Sístole & El (sin nombre) & Cariñoso y afectuoso. & Hipócrita, consentido e inmaduro. \\
\hline Kalibre 35 & Andrés & Idealista & $\begin{array}{l}\text { Celoso, inseguro, amargado, } \\
\text { depresivo, malgeniado y egoísta. }\end{array}$ \\
\hline Los Niños Invisibles & Rafael & $\begin{array}{l}\text { Buen hijo, líder, curioso, } \\
\text { enamoradizo, soñador. }\end{array}$ & \\
\hline Bolívar Soy Yo & Santiago Miranda & Idealista y valiente. & $\begin{array}{l}\text { Enfermo mental, no mide las } \\
\text { consecuencias de sus actos. }\end{array}$ \\
\hline $\begin{array}{l}\text { La virgen de los } \\
\text { sicarios }\end{array}$ & Fernando Vallejo & Culto & $\begin{array}{l}\text { Amargado, impetuoso, imprudente, } \\
\text { depresivo y violento. }\end{array}$ \\
\hline
\end{tabular}

En 1990 el cine nacional se encontraba en un punto crítico desde un punto de vista industrial. Los resultados irregulares de la política del sobreprecio y las cuentas en rojo de FOCINE auguraban su cierre, que efectivamente se produciría en 1993. Ese año se estrenaron dos largometrajes diametralmente opuestos por el tipo de historia que contaban y el público al cual iban dirigidos: Amar y vivir y Confesión a Laura. Estos largometrajes expresan las dos tendencias que se encontrarían en el cine nacional de los siguientes años: películas intimistas, adoradas por la crítica y de poco público vs. historias televisivas llevadas a la pantalla.

Sobre las segundas, afirma Navas (2006): Veo en el cine Colombiano una saturación de estereotipos, de facilismos deprimentes, de poca investigación y poca humanidad. Mucho personaje importado de telenovelas, mucha lógica de actuación en los actores tipo televisión. Se busca trabajo y dinero, pero no se buscan los personajes ni sus historias.

En primera instancia, Amar y vivir había sido una exitosa serie de televisión y fue llevada al cine por Carlos Duplat con prácticamente las mismas condiciones de la serie original (el mismo argumento, los mismos personajes y hasta los mismos actores). Esta práctica de contar historias televisivas en el cine, que en los últimos años se ha hecho muy común, apunta a un éxito casi 
seguro por la cercanía de los espectadores con el lenguaje televisivo, aunque se cuestione su aporte narrativo. No hay datos de taquilla de este año, pero es claro que Amar y vivir no alcanzó a recuperar su inversión inicial, aunque estuvo muy por encima de la taquilla de otras películas colombianas de su época.

Confesión a Laura, por su parte, es una de las películas más valoradas por la crítica nacional e internacional por su aporte narrativo y la profundidad de sus personajes. Su protagonista es un hombre común, bastante lejano al arquetipo de héroe por su condición pusilánime y de absoluta dominación por parte de su mujer que, sin embargo, emprende un viaje interior hacia su liberación ocurrida durante sólo una noche de reflexión junto con Laura, su vecina y nueva mejor amiga con la que pasa la noche en medio del desorden público organizado por la muerte del candidato liberal a la presidencia, Jorge Eliécer Gaitán, en 1948.

De igual manera y como característica relevante, el personaje antagónico (Josefina) es casi siempre visto desde la casa de enfrente, por lo que nunca se nos revela su esfera íntima, mientras que Santiago y Laura se van develando a lo largo de la película en la medida en que conquistan espacios de la casa. Estos personajes pasan de lo social (el vano de la puerta y la sala), lo personal (la cocina) a lo íntimo (la alcoba) y esto hace que poco a poco se vayan revelando sus características más privadas hasta llegar al final con una profunda evolución de cada uno de los personajes, pero fundamentalmente de Santiago, el protagonista.

1993 fue un año muy importante por el estreno de dos películas emblemáticas para el cine colombiano, similares en medio de sus profundos contrastes: La estrategia del caracol y La gente de la Universal. Podríamos decir, para ilustrar lo anterior, que la primera historia está protagonizada por prototipos en los que se resaltan fundamentalmente los valores y la astucia del hombre y la mujer colombianos, mientras que en la segunda se ve claramente la situación hostil del país y la caracterización de unos personajes bizarros llevados al extremo del individualismo y el egoísmo.

La estrategia del caracol es una película de Sergio Cabrera, director con formación cinematográfica en China y de tendencia izquierdista. La película fue estrenada con grandes expectativas y el apoyo de la productora Caracol TV (en una época en la que no existían los canales privados y esta práctica no era común).

La historia representa la lucha de un grupo de inquilinos de una antigua pensión del centro de Bogotá contra el dueño del inmueble, el millonario Holguín. El personaje principal de la historia es el Dr. Romero, más conocido como El perro, abogado no titulado y defensor de la causa, y como caso interesante tenemos dos antagonistas de diferente nivel en la historia: el Dr. Holguín y el abogado Víctor Honorio Mosquera, que es como su representante, su vocero, frente a los habitantes de la casa. Es interesante resaltar que en este caso los antagonistas son villanos con una moral absolutamente cuestionable, pero con características divertidas que pueden generar cierta simpatía en el público. Es importante anotar, igualmente, que el Dr. Romero posee características fundamentalmente positivas y un altruismo que le hace trabajar pensando sólo en los demás, por lo que se erige como el personaje más heroico de las películas de la muestra.

Finalmente es importante resaltar que, como ocurre con otras películas colombianas, La estrategia del caracol nombra a sus personajes de acuerdo a su caracterización, teniendo en cuenta que los personajes antagónicos (la clase alta) son representados con apellidos y los demás con su nombre. En ese sentido, tenemos al Dr. Romero, El perro, que es una manera muy común en Colombia de llamar a aquellos que son astutos y maliciosos. Este personaje rescata en su caracterización la solidaridad, la astucia y la "malicia" características del colombiano cuando decide respaldar a su comunidad. 
La gente de la Universal, por su parte, narra las peripecias de un grupo de detectives que, en medio de la investigación sobre un caso, se ven envueltos en un conflicto personal de celos y violencia.

Los protagonistas de esta historia y el común de los personajes son presentados fundamentalmente a partir de sus defectos. Se trata de seres dobles, falsos, con características contradictorias en su personalidad por lo que, en términos de la narrativa, la historia está llena de villanos.

Diógenes, el protagonista, es un personaje fundamentalmente negativo; es hipócrita, celoso, abusivo, machista, imperativo, impotente y ventajoso. Tiene en común con El Perro de La estrategia su habilidad para resolver los problemas desde el sentido común y la malicia indígena (término muy común en Colombia para designar el uso del conocimiento popular, generalmente de forma maliciosa y malintencionada). Todos los personajes principales aparecen revelados en sus aspectos más íntimos en algunos momentos de la historia y esta característica es interesante, pues allí adquieren volumen los personajes y podemos descubrir a un Diógenes frustrado e inseguro, características que pueden hacerlo un poco simpático a ojos de los espectadores.

En La deuda (1997) ocurre una situación atípica y es que el protagonista aparece algo difuso en dos personajes que podrían ocupar su posición: El turco y Begonia. La historia gira alrededor de la muerte de El Turco, un prestamista que vive en un pequeño pueblo y se desarrolla posteriormente a este acontecimiento.

El turco está muerto desde el principio de la historia y Begonia, que fue su mujer, aparece como la única del pueblo que está triste por su partida. Podría pensarse que Begonia es la protagonista, pues se trata de un personaje que tiene características fundamentalmente positivas y completamente opuestas a las de los antagonistas, pero realmente es poco lo que se conoce de ella y es así como el turco, desde su ausencia, termina siendo el protagonista de la historia, ya que se dedica a atormentar a sus acreedores durante la historia. Por obvias razones, es difícil que pueda hablarse de héroes y villanos en una historia en la que los principales son tan pobremente caracterizados.

En 1998 se estrenó La Vendedora de rosas, el segundo largometraje del director antioqueño Víctor Gaviria. La historia reafirmaba la marca documental en la ficción de Gaviria, tal como se había presentado en Rodrigo D: No futuro su película anterior, en donde también podía verse una historia basada en hechos reales e interpretada por actores naturales, evidenciando una alta influencia de movimientos como el Neorrealismo Italiano y el Cinema Novo Brasileiro. La historia, basada en el cuento La pequeña cerillera de Andersen (1835); está protagonizada por una niña de la calle, vendedora de rosas, y su deseo de celebrar una navidad en familia.

Esta película se desarrolla fundamentalmente en exteriores y es la única de la muestra que se realiza con actores naturales, en su mayoría menores de edad. Estas dos circunstancias configuran características importantes de los personajes de la historia. En primer lugar, tenemos una protagonista que en algunas circunstancias aparece como alguien un poco ajeno al ambiente en que se desenvuelve y fundamentalmente a las características negativas de los personajes que la rodean.

En la historia aparece uno de los villanos más importantes de la muestra, el zarco, que curiosamente es basado en personajes de la vida real, lo que de entrada podría sugerir una reflexión importante sobre la dureza de nuestra realidad que supera en personajes a la ficción.

El zarco ${ }^{9}$ es un ser temido y odiado, agresivo y altamente violento y no teme hacer nada porque vive la vida con la certeza de que pronto podría morir. En contraste, Mónica es una niña trabajadora, emprendedora y buena amiga que aunque es vengativa y peleadora se caracteriza 
por su nobleza y por la añoranza de una vida familiar que ha perdido y que la navidad le recuerda permanentemente.

Según Jáuregui y Suárez (2002:372) Mientras que el constante interés del Nuevo Cine Latinoamericano es registrar y hacer una crítica política de la Historia, la preocupación de Gaviria es el registro de la memoria de individuos y sectores citadinos a punto de desaparecer. En otras palabras, se centra en la política de la historia con minúsculas, y en la experiencia humana cotidiana de sectores vistos y tratados como desecho.

El mismo Víctor Gaviria (2002) afirma: Yo no puedo sin traicionarme, hacer de corrector del habla, y de gramático y preceptor del buen decir de los actores naturales. Ese lenguaje es mucho más importante que la película misma porque allí está la historia (la de la ciudad, la de los muchachos, la de los muertos, la de la injusticia, la de las experiencias de vida, la de la solidaridad y la identidad) ("Violencia, representación y voluntad realista").

Soplo de vida de Luis Ospina (2000) es la segunda película de uno de los mejores documentalistas del país después de 17 años de su anterior largometraje Pura sangre y constituye un intento inédito por hacer cine de género, haciendo una apuesta por el cine negro que, obviamente, marcó características de iluminación, arte, actuación y caracterización de personajes.

La historia parte de la investigación por la muerte de "Golondrina", una hermosa mujer que fue asesinada probablemente por uno de sus amantes y es llevada por Emerson Roque Fierro, un investigador privado con gran cantidad de conflictos personales.

El protagonista se llama Emerson Roque Fierro y podría interpretarse que su nombre tiene relación con el hecho de ser fuerte como una roca y frío y agresivo como un fierro (nombre que en Colombia se usa para denominar popularmente al revólver).

Fierro es quien narra su historia desde una posición homodiegética y focalización cero de acuerdo con la tipología de Genette (1989) (es parte de la historia, aunque no el centro, y narra con un conocimiento omnisciente) y es relevante considerar su carácter de antihéroe; pues es un personaje que no inspira confianza en los demás, debido a su oscuro pasado, está lleno de conflictos personales y de inseguridad.

Ese mismo año se estrenaron Diástole y Sístole y La virgen de los sicarios, dos películas muy distintas en sus pretensiones y el público al cual se dirigían.

En el caso de Diástole y sístole, se trataba de una película "ligera", dirigida por un conocido y joven director de televisión, protagonizada por actores de la televisión y con una estructura completamente televisiva. La historia está estructurada alrededor de los encuentros y desencuentros de una pareja y está tejida mediante los "gags" o situaciones divertidas que se les presentan en el desarrollo de su relación.

La elección de Diástole y sístole en la muestra analizada obedece a la necesidad de incluir algunas películas con estética y narrativa televisivas y que responden al gusto de un buen porcentaje de espectadores.

En esta película aparece como aspecto relevante el hecho de que ningún personaje tiene nombre propio y son muy pocas las referencias a su situación laboral y profesional. Esta característica, que no es evidente para los espectadores, se justifica con la idea que tiene la historia de que los espectadores puedan sentirse identificados con los personajes principales al presentarse como seres "anónimos". Como aspecto relevante de la historia está el hecho de que todos los personajes están por los 30 años y que sólo cuatro de ellos tienen alguna función dentro de la historia $^{10}$. 
Como la película transcurre alrededor de la vida de una pareja y sus encuentros y desencuentros amorosos; tenemos dos protagonistas en los que descansan gran cantidad de funciones, pues a su vez ejercen la función de ser los "intereses románticos" y no hay ningún personaje antagónico, salvo ellos mismos en algunos momentos de la película.

La virgen de los sicarios, por su parte, es una película basada en el libro de Fernando Vallejo y llevada al cine por el director francés Barbet Schroeder, que ha dirigido una buena cantidad de conocidos filmes comerciales como Mujer soltera busca, Mariposas de la noche y Medidas desesperadas.

La película se basa en la historia del regreso de Fernando (personaje prácticamente autobiográfico de Fernando Vallejo) a la ciudad de Medellín y sus encuentros y desencuentros con la cultura local y, particularmente, con la violencia urbana.

El personaje principal es un hombre de unos cincuenta años, homosexual, que se enamora de un sicario y durante toda la historia se lamenta por las características de su ciudad natal y la violencia que allí se vive. El protagonista es un ser que genera fundamentalmente repulsión y expresa permanentemente su amargura e impulsos suicidas. Los personajes secundarios no alcanzan a ser desarrollados y sólo se presentan en dos esferas: la "profesional", como excelentes sicarios y la íntima, cuando tienen relaciones amorosas o sexuales con el protagonista.

La película es una mirada desde afuera sobre la cultura colombiana y sus personajes terminan siendo una excusa para lanzar una crítica aguda a la realidad del país. El hecho de que la historia del libro esté narrada en primera persona dificulta seguramente el hecho de realizar la adaptación a la gran pantalla, por cuanto se pierde distancia y perspectiva frente a la caracterización del protagonista, que termina siendo una imitación del mismo autor, Fernando Vallejo.

Kalibre 35, en 2001, constituyó una mirada del cine colombiano sobre el cine colombiano. La trama gira en torno a tres amigos que sueñan con realizar una película en las condiciones adversas que en el momento existían para hacerlo y que deciden, en una medida desesperada, asaltar un banco para obtener el dinero.

En esta historia aparece el concepto de la trilogía de amigos, que aquí se evidencia en dos personajes con características contrarias (Andrés y Luis) y un tercero mediador (Federico). Los nombres de los personajes pueden ser interpretados, igualmente, como un homenaje a cuatro grandes personalidades del cine de autor: Federico Fellini, Akira Kurosawa y los colombianos Luis Ospina y Andrés Caicedo.

De igual manera funciona (aunque no es el centro de la película) un triángulo amoroso entre Akira, Luis y Andrés. Esta condición nos lleva a descubrir que son cuatro los personajes principales de la historia y que ninguno de ellos encarna la función antagónica, pues en esta película (al estilo de las tragedias) podríamos decir que el destino es el antagonista.

Si tomamos a Andrés como el protagonista por su número de apariciones, de acuerdo con el criterio de García Jiménez (1993), podemos encontrar a un personaje que, si bien es idealista, realmente tiene pocas cualidades que permitan que el espectador logre identificarse con él y su sistema de valores al punto de justificar un crimen (robo).

Los Niños Invisibles de 2002 constituye una notable excepción también en la muestra de las películas de los últimos años por ser protagonizada por niños y desarrollarse en un contexto fundamentalmente rural (un caluroso pueblo a orillas del río Magdalena). La película cuenta la historia de Rafael, un niño de 11 años que, con su grupo de amigos, intenta encontrar la invisibilidad para acercarse a una niña que le gusta.

El protagonista, Rafael, aparece además a los 50 años como narrador de la película, contando la historia desde una posición autodiegética con focalización cero ${ }^{11}$. Esto implica que Rafael adulto 
está contando su propia historia con un conocimiento de los hechos que va más allá de lo que cualquier personaje sabe.

Durante el desarrollo del relato Rafael tiene 11 años y es el personaje más importante junto con dos amigos de su misma edad, Fernando y Gonzalo que cumplen la función de contraste (Gonzalo) y equilibrio (Fernando). Vuelve a aparecer la trilogía de amigos, que es común en el cine y tiene sentido pues permite a lo largo de la trama el establecimiento de alianzas temporales de dos personajes contra uno. En el caso de estos tres amigos, sus características se oponen y complementan a lo largo de la película.

Rafael tiene algunas características positivas, pero está lejos de ser un héroe, narrativamente hablando, y sus deseos y miedos son los mismos que podría sentir un niño de su edad en la época en la que la historia se desarrolla.

Finalmente, realizamos el análisis de la película Bolívar Soy Yo de Jorge Alí Triana (2002). Esta película está inspirada en la historia real del actor colombiano Pedro Montoya, quien después de actuar durante muchos años como Bolívar en la televisión colombiana, empezó a actuar como tal al punto de sufrir serios desequilibrios mentales y creer que él mismo era Simón Bolívar.

En esta película se presenta una característica importante por el tipo de conflicto: Yo vs. Yo que hace que el protagonista sea al mismo tiempo su antagonista, debido a que desarrolla una doble personalidad que está continuamente cambiando entre él y su personaje. Santiago, el actor, está insatisfecho con la sociedad y se siente un héroe, por lo que fácilmente se compenetra con su personaje de Bolívar y al asumir un rol de antagonista se convierte en un catalizador.

Otro personaje catalizador en esta historia es el director de la telenovela que necesita matar a Bolívar, oponiéndose de esta forma a los deseos de Santiago. Cuando el director intenta matar su otra personalidad (el personaje de Bolívar), ésta se hace más fuerte y termina apoderándose de Santiago. Una de sus dos personalidades se hace más fuerte y termina suprimiendo la otra.

\section{Discusión}

De acuerdo a lo expuesto, podemos decir que el cine colombiano de este período (1990-2003) carece de buenos protagonistas y constituye más un reflejo de lo que muchos pretenden que sea la "colombianidad" que de un estudio serio de personajes de carácter, que sostengan el peso de la historia y logren la identificación del público nacional. A pesar del avance de la industria colombiana después de la puesta en marcha de la ley del cine, esta situación parece no haber cambiado demasiado. Al respecto, Uribe (2009) dice que los personajes en el cine colombiano contemporáneo tienden a ser moralmente planos y las películas a pertenecer a una de dos categorías: o todos los personajes son buenos en el fondo (algo que nunca duda, por ejemplo, el protagonista sobre su amigo "caído en desgracia" en Las Cartas del Gordo), o todos son malos, egoístas, ambiciosos, corruptos, inescrupulosos, etc., como en Bluff.

Como mencionamos al inicio, la trama de la mayoría de las películas se fundamenta en la acción y el carácter de los personajes no está dado más allá de las acciones que desarrollan. Su caracterización está basada en un rol pasivo y no suelen ser constructores de acontecimientos narrativos, pues van con la corriente de la trama. Según Alba (2009),cada oportunidad de mostrar las particularidades de los hábitos, las costumbres y las problemáticas locales es aprovechada en detrimento de la construcción del carácter de los personajes, lo que permite un revelamiento de signos de la identidad local, pero a la vez una distancia del personaje y su función argumental. 
Como ocurre en el periodismo, el cine nacional suele incurrir en el hábito de seleccionar como sustento de sus historias las más escandalosas o polémicas y adaptarlas a un formato de ficción que intente entretener al gran público. Nuevamente, es una cuestión de posición crítica ya no ante el cine sino ante la realidad seleccionar las historias llenas de emociones extremas pero sobre todo descartar aquellas en las que, a pesar del drama subyacente, las personas actúan de una manera mucho más circunspecta (Uribe, 2009).

Coincidimos con Alba (2009) en que en muchas de las historias que cuenta el cine colombiano carecen de un protagonista individual para presentar a una especie de protagonista colectivo. Esta situación desdibuja la caracterización de los personajes que pueden fácilmente acercarse más al estereotipo lleno de lugares comunes que un prototipo que sea referente de la cinematografía nacional.

\section{Bibliografía}

ALBA, G. (2006) La narración en el largometraje colombiano de ficción 1950-2000 en Revista Razón y Palabra \# 49. México: Tecnológico de Monterrey

ALVAREZ, L (2001). El Cine en la Última Década del siglo XX: Imágenes Colombianas. Capítulo del libro Colombia Hoy de MELO J. Bogotá: Banco de la República.

ÁLVAREZ, C (1989). Sobre cine colombiano y latinoamericano. Bogotá: Universidad Nacional de Colombia.

ARISTÓTELES (1982). La Poética. Caracas: Universidad Central.

CARRIÈRE, J C y BONITZER, P (1991). Práctica del guión cinematográfico, Barcelona: Paidós.

FERNÁNDEZ, F (2005). El libro del guión. Madrid: Fundación Universitaria Iberoamericana.

GARCÍA JIMÉNEZ, J (1993). Narrativa Audiovisual. Madrid: Cátedra.

GARCíA, S (1989). Teoría y Práctica del Teatro. Bogotá: Teatro la Candelaria.

GAVIRIA, V (2002). Violencia, representación y voluntad realista. Entrevista con Víctor Gaviria realizada por Carlos Jáuregui. Pittsburgh: Serie tres ríos.

GENETTE, G. (1989). Figuras III. Barcelona: Lumen.

JÁUREGUI C y SUÁREZ J. (2002). Profilaxis, Traducción y Ética: La Humanidad "Desechable" en Rodrigo D, no futuro, La vendedora de rosas y La virgen de los sicarios en Revista Iberoamericana Vol. LXVIII \# 199.

LAURENS, M (1988). El vaivén de las películas colombianas (de 1977 a 1987). Bogotá: Contraloría General de la República.

MATUTE, P (2008). La resurrección del ave fénix ponencia presentada en el Panel sobre cine latinoamericano del Primer Encuentro Iberoamericano de Redes de Investigación en Comunicación Audiovisual y Periodismo

NAVAS, J (2006). Entrevista a Jorge Navas en Revista Kinetoscopio vol. 16 \# 75. Medellín: Centro Colombo Americano.

OSPINA, L (2002). Mi último soplo ¿qué es un "soplo de vida"?. Bogotá: Revista Número, \# 24.

PROPP, V (2000). Morfología del cuento. Madrid: Fundamentos.

POLTI, Georges. (1916). The Thirty-Six Dramatic Situations. Boston: The Writer, Inc.

PULECIO, E (1999). El siglo del cine en Colombia. Revista Credencial \# 112 
RIVERA, J (2007). Personajes con sello colombiano en Revista Anagramas vol. 11 \# 6, Universidad de Medellín.

SEGER, L (1993). Cómo convertir un buen guión en un guión excelente. Madrid: De Rial.

SEGER, L (2000). Cómo crear personajes inolvidables. Barcelona: Paidós.

URIBE, R (2009). Alma provinciana la posibilidad de películas adultas en el cine colombiano en http://provinciana.typepad.com/alma provinciana/2007/05/la posibilidad 3.html recuperado el 12 de Diciembre de 2009

VÉLEZ, JM (2007). Un cine de anécdotas en Revista Anagramas vol. 11 \# 6, Universidad de Medellín.

\footnotetext{
${ }^{1}$ Jefe del Área de Comunicación Audiovisual y Editor de la Revista Palabra Clave de la Universidad de La Sabana (Bogotá- Colombia). Magíster en Educación y Director de la Red Iberoamericana de Investigación en Narrativas Audiovisuales (Red INAV).

${ }^{2}$ Cabe resaltar, por ejemplo, la restauración de la película Bajo el cielo antioqueño de Arturo Acevedo (1925), que realizó la Fundación Patrimonio Fílmico Colombiano en 1997.

${ }^{3}$ Y lo que es más grave, muchas de períodos posteriores también.

${ }^{4}$ Este dato está basado en las cifras del Instituto Mexicano de Cinematografía, presentadas por Pedro Matute Villaseñor en el Panel sobre cine latinoamericano del Primer Encuentro Iberoamericano de Redes de Investigación en Comunicación Audiovisual y Periodismo realizado en la Universidad de La Sabana en octubre de 2008

${ }^{5}$ Es importante mencionar el aporte de Santiago García en su texto Teoría y Práctica del Teatro (1989) en el que utiliza la tipología de situaciones, acciones y personajes con sutiles diferencias pero la misma intención que García Jiménez.

${ }^{6}$ Entrevista realizada para la investigación "personajes, acciones y escenarios en el cine colombiano 19902005”. Grupo de investigación IMAGO, Universidad de Medellín, 2007.

${ }^{7}$ Es importante aquí retomar a Linda Seger (2000) cuando establece la importancia de la historia de fondo para caracterizar a los personajes. Este concepto parte de considerar la vida del personaje fuera de la trama que se presenta en el relato.

${ }^{8}$ Entrevista a Jorge Navas. Revista Kinetoscopio Nov. 30 de 2006.

${ }^{9}$ En Colombia se le llama zarco a las personas de ojos claros.

${ }^{10}$ De acuerdo a la tipología planteada por Seger (1993)

${ }^{11}$ De acuerdo a la tipología de narradores planteada por Genette (1989) y recogida por García Jiménez (1993).
} 